\title{
SPATIAL VARIABILITY OF SOIL MICRONUTRIENTS (Cu, Fe, Zn \& Mn) AND POPULATION DYNAMIC OF MYCOFLORA IN POTATO FIELDS OF CKNP REGION GILGIT-BALTISTAN PAKISTAN
}

\author{
Azhar Hussain ${ }^{1, *}$, Muhammad Saeed Awan', Sartaj Ali', Sher Wali Khan ${ }^{2,}$, Francesco Morari ${ }^{3}$ \\ and Shamsher Ali ${ }^{4}$
}

\author{
${ }^{1}$ Department of Agriculture and Food Technology Karakoram International University Gilgit Baltistan, Pakistan; \\ ${ }^{3}$ Department of Agronomy, Food, Natural Resources, Animals and Environment, Agripolis, University of Padova 16, \\ 35020 Legnaro (Padova), Italy; \\ ${ }^{4}$ Department of Chemistry, Karakoram International University Gilgit Baltistan, Pakistan. \\ *Corresponding author's e-mail: azharkiu@gmail.com,dr.sherwali@kiu.edu.pk
}

\begin{abstract}
The main aim of current study was to explore the spatial variability of micronutrients $(\mathrm{Cu}, \mathrm{Fe}, \mathrm{Zn} \& \mathrm{Mn})$ and mycoflora in a potato growing valleys of CKNP region, Gilgit-Baltistan, Pakistan. Ninety sixty soil samples were collected by a random sampling technique using Global Positioning System (GPS). In general, soils of survey valleys are loamy or silty loam with slightly alkaline $\mathrm{pH}$ and low to medium organic matter. Geographic Information System (GIS) was applied for micronutrients mapping of the analyzed data obtained from laboratory test. Results indicated that micronutrients $(\mathrm{Cu}, \mathrm{Fe}$ and $\mathrm{Mn})$ were found high except $\mathrm{Zn}$. The Zinc concentration was low in 57.29\% samples, medium in $30.20 \%$ samples and high in $12.50 \%$ samples respectively. The GIS mapping of soil micronutrients can be used in precision farming studies with the application of fertilizers and this approach is also proposed for the evaluation of sustainable soil management practices. The observed spatial variability of micronutrients helps potato growers in crop management decisions to increase productivity and improve farmer's livelihood. Knowledge and conservation of soil mycoflora is essential for sustainable agriculture development. In the current study a total number of thirteen mycoflora species were isolated from the composite soil sample of four valleys. The valley wise population per gram of soil was recorded as $24 \times 10^{-6}$ in Bagrote, $18 \times 10^{-6}$ in Haramosh, $15 \times 10^{-6}$ in Hoper and $26 \times 10^{-6}$ in Shigar valley. The most dominant among them were Aspergillus flavus, Mucor species, Rhizopus stolonifer, Penicillium species and Alternaria alternate.
\end{abstract}

Keywords: Micronutrients, spatial variability, mycoflora, potato fields, soil fertility.

\section{INTRODUCTION}

Soil plays a key role for sustainable crop production and food security. Fertility of soil is intrinsic ability of a soil to supply micro-macro nutrients in sufficient amounts for getting maximum crop production (Von, 1988). Soil nutritional status is key indicators of soil quality (Jansen et al., 1995). Soil fertility influence by land use and management practices and its quality varies either spatially or temporally from field to field or on regional scale (Sun et al., 2003). Regardless of the spatial and temporal changes of soil properties in small and large scales, awareness of how these changes occur for increasing profitability and sustainable agriculture management is necessary (Ayoubia et al., 2007). Determining soil variability is important for ecological modeling, environmental predictions, precise agriculture and management of natural resources (Hangsheng et al., 2005). Farmers all over the world normally take care of macronutrients rather than micronutrient application in the soils, thereby resulting increased deficiencies of micronutrients. On the other hand, micronutrients have an important role in balanced plant nutrition for the stabilization of crop yield of an area (Rattan and Sharma, 2004).

Soil micronutrient is equally important as the macro nutrient for crop growth, and often they are present in small quantities in the soil. Deficiency of micronutrients can lead to severe depression in crop growth, yield, and crop quality. Its availability in soil is depending on the parent material and pedogenic process (White and Zasoski, 1999). In the present era of precision farming, the inputs such as fertilizer, crop varieties and management practices are matched precisely with the variability in soil and climatic conditions so that inputs are applied as per the location specific requirements of the crop. Further, the monitoring of the same sites has remained a major problem due to absence of geo coded location of the sampling sites.

The advent of information technology have provided tools like Global Positioning System (GPS), Geographical Information System (GIS) which helps in collecting a systematic set of geo referenced samples and generating the spatial data about the distribution of nutrients (Sharma, 2007). The maps generated through remote sensing helps in 
delineating the homogenous units to decide the sampling size and thereby saving a lot of time. This will also help to monitor the changes in micronutrient status over a period of time as geo-referenced sampling sites can be revisited with the help of GPS which is otherwise difficult in the random sampling (Sood et al., 2004).

Soil microorganisms play active role to increase fertility and plant growth because they are involved a number of biochemical transformation and mineralization activities. Method of cultivation and management practices found to have greater influence on the activity of soil mycoflora (McGill et al., 1980). Soil mycoflora plays a pivotal role in evaluation of soil conditions and in stimulating plant growth (Kiran et al., 1999).

Microorganisms play significant role for enhancing soil fertility as well as plant growth. They are involved in many biochemical reaction including nutrient transformation and mineralization activities in soils. Among microbioata mycoflora are an important component due its abundance. The conservation of soil mycoflora in agriculture field becomes very essential for the sustainable agriculture development (Gnanasekaran et al., 2015). Soil mycoflora are essential for ecosystem functioning of soil. Particularly in forest and agricultural soils, they play a key role in many necessary processes such as decomposition of organic matter and release of element by mineralization. It is important part of the soil micro biota and plays a focal role in nutrient cycling by regulating soil biological activity. The amount of organic and inorganic materials present in the soil has a direct effect on the fungal population of the soil (Warcup et al., 1950; Christensen, 1989; Ainsworth, 1995). The soil mycoflora naturally constitutes more biomass as compared to bacteria, depending on soil depth and nutrient conditions. The function of fungi in the soil is tremendously multifaceted one and it is fundamental to the soil ecosystem. They perform ecological services that strongly impact the quality of human life and have enormous potential for providing economic benefits. Mycoflora play a focal role in nutrient cycling by regulating soil biological activity (Arunachalam et al., 1997).

This is first ever study on the spatial variability of soil micronutrients and population dynamic of mycoflora in the study area. The results of micronutrient may use in determining site specific nutrient management practices, minimize cost of cultivation and preventing environmental pollution. Whereas, diversity of soil mycoflora may provide information related to soil conservation and sustained ecological balance of the area. Keeping in view the fact, the current endeavor was aimed to assess the spatial variability of micronutrients and population dynamic in the soil of potato growing valleys of CKNP region Gilgit-Baltistan Pakistan.

\section{MATERIALS AND METHODS}

Study area: Central Karakoram National Park (CKNP) covers three major districts i.e. Gilgit, Skardu and Ghanche. In 1993, Govt of Pakistan declared CKNP as a national park. Total covered area is over ten thousand $\mathrm{km}^{2}$ and encompassing largest glacier; Baltoro, Hispar-Biafo and Siachen of the world outside the Polar Regions whereas the buffer zone $\left(7,400 \mathrm{~km}^{2}\right)$ of CKNP is home to about 97,608 people residing in 230 village settlements. Mixed mountain agriculture is main activity of the locals. In the current study a total of 96 soil samples were collected from four valleys of CKNP region Gilgit-Baltistan Pakistan at 0-20 cm depth after harvesting of potato crop. These samples were dried, ground, sieved and stored until used (Fig. 1).

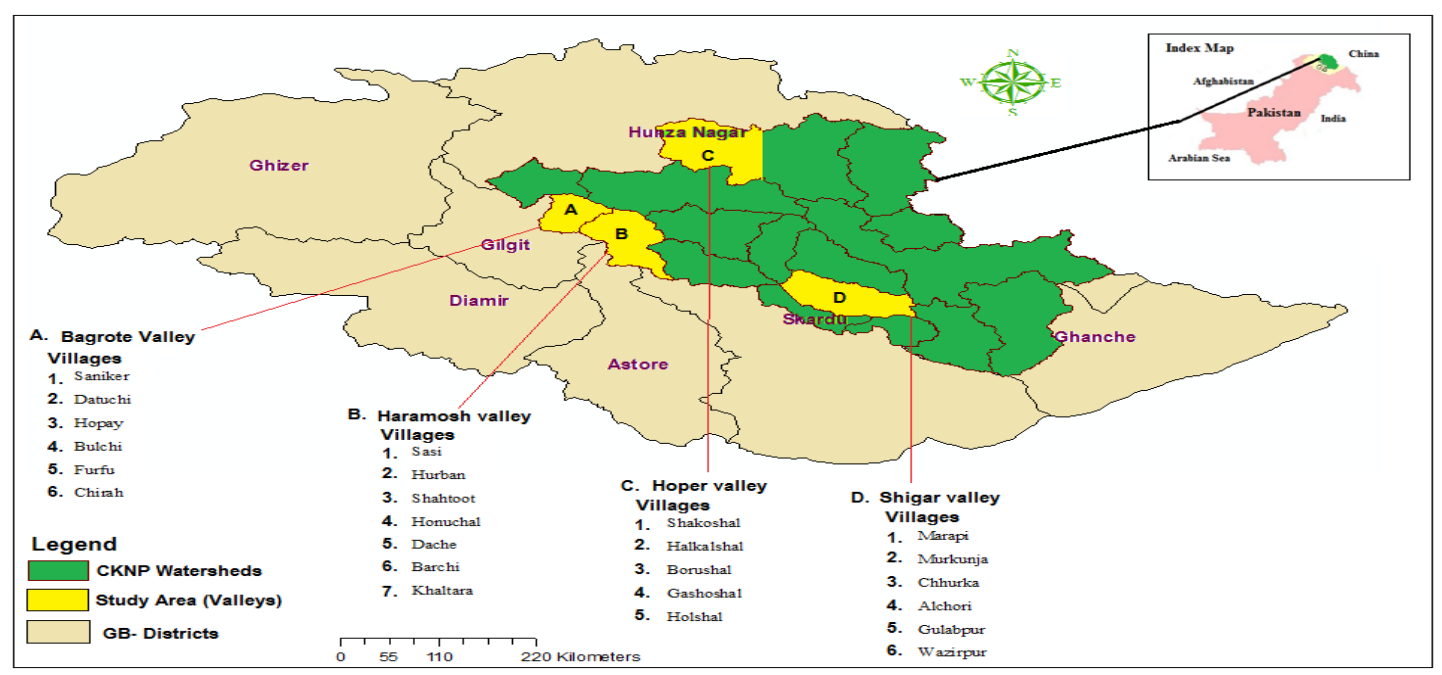

Figure 1. Map of Central Karakoram National Park, Gilgit-Baltistan, Pakistan. 
Table 1. The criteria used to categorize the soil samples (O.M \% and soil saturation).

\begin{tabular}{lllc}
\hline & \multicolumn{1}{c}{ Saturation \% } & Organic Matter \% \\
\hline $0<20$ & Sand or loamy sand & Low & $<0.86$ \\
$20-35$ & Sandy loam & Medium & $0.86-1.29$ \\
$35-50$ & Loam or silty loam & High & $>1.29$ \\
\hline $50-65$ & Clay lo &
\end{tabular}

50-65 Clay loam

65-35 Clay

Soil pH, organic matter and saturation percentage: Soil $\mathrm{pH}$ was determined with the help of pH meter (InoLab, WTW Germany) while organic matter (OM) was determined by the modified method of Walkely and Black reported by Nelson and Sommers (1982). Soil saturation \% was determined as described by Milk et al. (1985).

$$
\text { Saturation } \%=\frac{\text { Amount of water added }(\mathrm{g}) \times 100}{\text { Mass of air dry soil }(\mathrm{g}) \times(100-\mathrm{Pw}) / 100}
$$

The criteria used to categorize the soil organic matter and saturation percentage is given in Table 1 (Malik et al., 1984). Micronutrients: Ammonium bicarbonate diethylene triamine penta acetic acid (AB-DTPA) extractable $\mathrm{Cu}, \mathrm{Fe}, \mathrm{Zn}$ and $\mathrm{Mn}$ were determined using the method given by Soltonpour and Schawab 1977. Thematic maps were generated for each of the soil micronutrients using Inverse Distance Weighted (IDW) interpolation provided in Arc GIS 10.1 software (Kartik et al., 2014). Critical soil test values of AB-DTPA extractable $\mathrm{Cu}$, $\mathrm{Fe}, \mathrm{Zn} \& \mathrm{Mn}$ described by Soltanpour, 1985 as given below were used for comparison:

Table 2. The criteria used to categorize the soil samples for various classes of micronutrients.

\begin{tabular}{cccc}
\hline Micronutrients & \multicolumn{3}{c}{ Nutrient Content $\left(\mathbf{m g ~ k g}^{-1}\right)$} \\
\hline & Low & Medium & High \\
$\mathrm{Cu}$ & $<0.3$ & $0.3-0.5$ & $>0.5$ \\
$\mathrm{Fe}$ & $<3.0$ & $3.0-5.0$ & $>5.0$ \\
$\mathrm{Mn}$ & $<0.6$ & $0.6-1.0$ & $>1.0$ \\
$\mathrm{Zn}$ & $<1.0$ & $1.0-1.5$ & $>1.5$ \\
\hline
\end{tabular}

Mycoflora diversity: Composite soil samples were collected from four valleys (Bagrote, Haramosh, Hoper and Shigar) of potato growing region of CKNP. These samples were packed in polythene bags and used to enumerate mycoflora diversity using standard method of Warcup, (1950) by serial dilution techniques $\left(10^{-3}, 10^{-4}\right.$ and $\left.10^{-6}\right)$ using PDA (potato dextrose agar). The medium was prepared and sterilized at $121^{\circ} \mathrm{C}(15$ lbs pressure) for 15-20 minutes. Then it was supplemented with $1 \%$ streptomycin to prevent bacterial growth. The medium was poured into the sterile petri plates and allowed to solidify. Then serially diluted soil samples were directly inoculated into petri plates containing PDA medium. The inoculated plates were incubated at $28 \pm 2^{\circ} \mathrm{C}$ for seven days. Four replicates of each sample were maintained and experiment was repeated twice. Percentage of occurrence of mycoflora per gram of soil was calculated by using the formula:

$$
\mathrm{OP}=\frac{T \mathrm{n} \cdot \mathrm{CFU} \cdot \mathrm{Ispp}}{\mathrm{Tn} \cdot \mathrm{CFU} \cdot \mathrm{Aspp}} \times 100
$$

$(\mathrm{OP}=$ Occurrence percentage $; \mathrm{Tn}=$ Total number; $\mathrm{CFU}=$ Colony forming unit; I. $s p p=$ Individual species; A. $s p p=$ All species).

Identification of mycoflora: Mycoflora were identified macroscopically by observing colony features (Colour and Texture) and microscopically by staining with lacto phenol cotton blue and observe under compound microscope. The mycoflora identified with the help of literature (Barnett, 1998; Ellis, 1993; Gilman, 2000; Nagamani et al., 2006).

\section{RESULTS}

Soil pH, organic matter and Saturation percentage: The data regarding the $\mathrm{pH}$, Organic matter and saturation $\%$ of soil is presented in Table 3. The mean $\pm \mathrm{SD}$ values recorded for $\mathrm{pH}$, organic matter and saturation percentage were $7.99 \pm 0.06$, $0.99 \pm 0.12$ and $41.37 \pm 2.96$ in Bagrote valley while $7.61 \pm 0.20$, $1.02 \pm 0.13$ and $39.10 \pm 2.22$ was recorded in Haramosh valley. In Hoper and Shigar valley, the mean \pm SD values of soil $\mathrm{pH}$ $(7.84 \pm 0.27,7.77 \pm 0.25)$ organic matter $(1.02 \pm 0.11,1.0 \pm 0.12$ and saturation percentage $(43.35 \pm 2.99,40.12 \pm 2.193)$ were noted. The overall study showed that the soil of area was loamy or silty loam with 7.23-8.30 pH range whereas organic

Table 3. Soil $\mathrm{pH}, \mathrm{OM}(\%)$ and Saturation $(\%)$ in the valley of CKNP region Gilgit-Baltistan $(\mathrm{n}=96)$.

\begin{tabular}{lcccccc}
\hline Valleys & \multicolumn{2}{c}{ pH } & \multicolumn{2}{c}{ OM\% } & \multicolumn{2}{c}{ Sat.\% } \\
\cline { 2 - 7 } & Range & Mean \pm SD & Range & Mean \pm SD & Range & Mean \pm SD \\
\hline Bagrote & $7.80-8.10$ & $7.99 \pm 0.06$ & $0.80-1.22$ & $0.99 \pm 0.12$ & $37.0-48.0$ & $41.37 \pm 2.96$ \\
Haramosh & $7.23-7.98$ & $7.61 \pm 0.20$ & $0.75-1.26$ & $1.02 \pm 0.13$ & $35.0-45.0$ & $39.10 \pm 2.22$ \\
Hoper & $7.38-8.30$ & $7.84 \pm 0.27$ & $0.84-1.30$ & $1.02 \pm 0.11$ & $39.0-48.0$ & $43.35 \pm 2.99$ \\
Shigar & $7.35-8.13$ & $7.77 \pm 0.25$ & $0.78-1.21$ & $1.00 \pm 0.12$ & $36.0-44.0$ & $40.12 \pm 2.193$ \\
\hline
\end{tabular}


matter content of the study area was low (15.62\%), medium $(83.33 \%)$ and adequate $(1.04 \%)$ (Table 4$)$.

Table 4. Soil pH, OM (\%) and Saturation (\%) categorized in different ranges of study area.

\begin{tabular}{llccc}
$\begin{array}{l}\text { Valley } \\
\text { Soil status }\end{array}$ & N.S & Low & $\begin{array}{c}\text { OM \% } \\
\text { Medium }\end{array}$ & High \\
\hline Bagrote & $\mathrm{N}=24$ & $6(25.0)$ & $18(75.0)$ & $0.0(0.0)$ \\
Haramosh & $\mathrm{N}=28$ & $2(7.1)$ & $26(92.9)$ & $0.0(0.0)$ \\
Hoper & $\mathrm{N}=20$ & $3(15.0)$ & $16(80.0)$ & $1.0(5.0)$ \\
Shigar & $\mathrm{N}=24$ & $4(16.7)$ & $20(83.3)$ & $0.0(0.0)$ \\
Mean & $\mathrm{N}=96$ & $15(15.6)$ & $80(83.3)$ & $1.0(1.0)$ \\
Soil pH Range & \multicolumn{3}{c}{$\begin{array}{c}7.23-8.30 \\
\text { Saturation \% }\end{array}$} \\
\hline
\end{tabular}

Spatial variability of micronutrients: Spatial variability of micronutrients $(\mathrm{Cu}, \mathrm{Fe}, \mathrm{Zn}$ and $\mathrm{Mn})$ and mycoflora were assessed in twenty four villages that consist of four valleys of Central Karakoram National Park Gilgit-Baltistan. Results revealed that the mean concentration of $\mathrm{Cu}, \mathrm{Fe}, \mathrm{Mn}$ and $\mathrm{Zn}$ in potato growing soil of Bagrote valley was found to be 3.58 , 7.43, 7.66 and $0.96 \mathrm{mg} \mathrm{kg}^{-1}$ (Table 5). All soil samples exhibited high concentration of $\mathrm{Cu}, \mathrm{Fe}$ and $\mathrm{Mn}$ except $\mathrm{Zn}$ which was low in $58.3 \%$ and medium in $41.6 \%$ tested samples. Mapping of micronutrients by GIS techniques showed that above $70 \%$ area contains $\mathrm{Cu}$ concentration in the range of $3.33-4.22 \mathrm{mg} \mathrm{kg}^{-1}, 66.6 \%$ area falls in the range of $6.22-7.51 \mathrm{mg} \mathrm{kg}^{-1}$ of $\mathrm{Fe}, 75 \%$ area falls in the range of $0.92-$ 1.12 , $\mathrm{mg} \mathrm{kg}^{-1}$ of $\mathrm{Zn}$ and $58.3 \%$ areas fall in the range of 7.80$10.06 \mathrm{mg} \mathrm{kg}^{-1} \mathrm{Mn}$ concentration (Fig. 2). Similarly mean values of micronutrients in Haramosh valley were recorded as

Table 5. Spatial variability of micronutrients in the valley CKNP region Gilgit-Baltistan $(n=96)$.

\begin{tabular}{lcccccccc}
\hline \multirow{2}{*}{ Valleys } & \multicolumn{2}{c}{ Cu $\left(\mathbf{m g ~ k g}^{-\mathbf{1}}\right)$} & \multicolumn{2}{c}{ Fe } & \multicolumn{2}{c}{ Zn } & \multicolumn{2}{c}{ Mn } \\
\cline { 2 - 9 } & Range & Mean \pm SD & Range & Mean \pm SD & Range & Mean \pm SD & Range & Mean \pm SD \\
\hline Bagrote & $2.44-4.33$ & $3.58 \pm 0.48$ & $6.22-10.12$ & $7.43 \pm 0.93$ & $0.73-1.12$ & $0.96 \pm 0.09$ & $5.44-10.08$ & $7.66 \pm 1.28$ \\
Haramosh & $2.44-4.89$ & $3.38 \pm 0.57$ & $4.86-12.22$ & $8.85 \pm 1.79$ & $0.65-1.46$ & $0.99 \pm 0.18$ & $6.24-11.19$ & $8.87 \pm 1.33$ \\
Hoper & $2.88-4.92$ & $3.41 \pm 0.59$ & $6.18-13.24$ & $9.25 \pm 2.03$ & $0.74-1.86$ & $1.06 \pm 0.27$ & $8.15-12.13$ & $10.34 \pm 1.37$ \\
Shigar & $3.18-4.66$ & $3.54 \pm 0.34$ & $10.46-13.55$ & $12.53 \pm 0.3$ & $0.62-1.22$ & $0.96 \pm 0.15$ & $10.12-12.08$ & $10.81 \pm 0.49$ \\
Mean & $2.73-4.70$ & $3.47 \pm 0.49$ & $6.93-12.28$ & $9.51-1.26$ & $0.68-1.41$ & $0.99 \pm 0.17$ & $7.48-11.37$ & $9.42 \pm 1.12$ \\
\hline
\end{tabular}

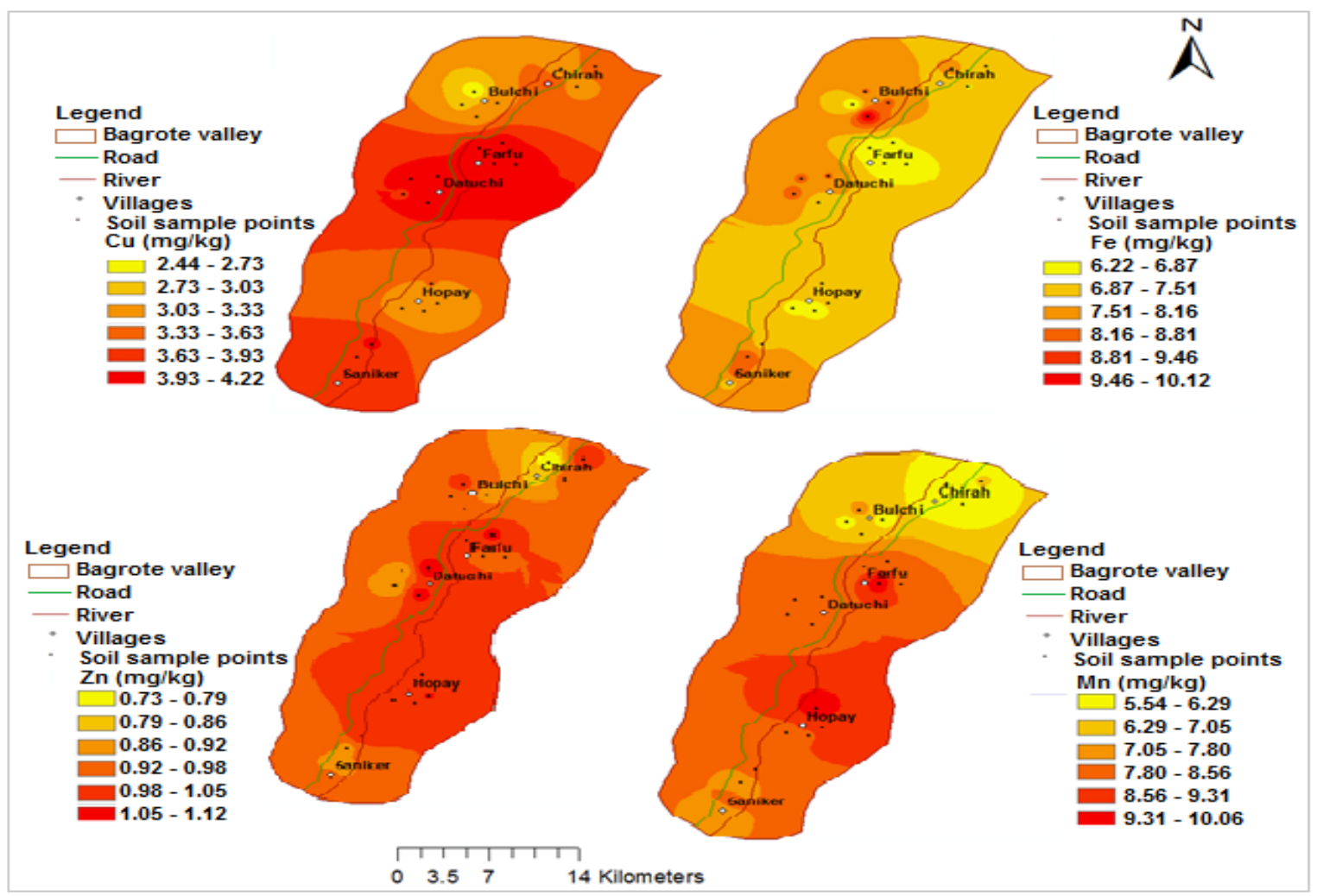

Figure 2. Mapping of micronutrient in villages of Bagrote valley. 
3.38 Cu, 8.85 Fe, 0.99, $\mathrm{Zn}$ and $8.87 \mathrm{mg} \mathrm{kg}^{-1} \mathrm{Mn}$. The extractable $\mathrm{Cu}$ and $\mathrm{Mn}$ was high in all tested samples, whereas, $\mathrm{Fe}$ was found medium in $3.58 \%$ and high in $96.2 \%$ tested samples, furthermore, $\mathrm{Zn}$ was low in $6.2 \%$, medium in $14.2 \%$ and high in $21.4 \%$ investigated samples (Table 6). Macronutrients map showed that $64.28 \%$ area contains $>3.11$ $\mathrm{mg} \mathrm{kg}^{-1} \mathrm{Cu}$ concentration, $78.5 \%$ area having $>7.31 \mathrm{mg} \mathrm{kg}^{-1}$ concentration of $\mathrm{Fe}, 67.8 \%>0.91 \mathrm{mg} \mathrm{kg}^{-1}$ and $75 \%>7.89 \mathrm{mg}$ $\mathrm{kg}^{-1}$ contains $\mathrm{Zn}$ and $\mathrm{Mn}$ concentrations respectively (Fig. 3). Micronutrient concentrations in Hoper valley were found to be 3.41 $\mathrm{Cu}, 9.25 \mathrm{Fe}, 1.06 \mathrm{Zn}$ and 10.34 $\mathrm{Mn} \mathrm{mg} \mathrm{kg}{ }^{-1}$. Result indicated that $\mathrm{Cu}, \mathrm{Fe}$ and $\mathrm{Mn}$ were high in all soil samples except $\mathrm{Zn}$ which was low in 50\%, Medium 35\% high in $15 \%$ tested soil samples (Table 3). Map of Hoper valley showed $80 \%$ tested soil samples contain $<3.89 \mathrm{mg} \mathrm{kg}^{-1}$ concentration of $\mathrm{Cu}, 60 \%<9.70 \mathrm{mg} \mathrm{kg}^{-1}$, Fe $90 \%$ sample contain $<1.29 \mathrm{mg}$ $\mathrm{kg}^{-1}$ of soil (Fig. 4). In Shigar valley mean value of $\mathrm{Cu} 3.54$ $\mathrm{mg} \mathrm{kg}^{-1}, \mathrm{Fe} 12.53 \mathrm{mg} \mathrm{kg}^{-1}, \mathrm{Zn} 0.96 \mathrm{mg} \mathrm{kg}^{-1}$ and $\mathrm{Mn} 10.81 \mathrm{mg}$ $\mathrm{kg}^{-1}$ was detected. All soil samples exhibited high concentration of $\mathrm{Cu}, \mathrm{Fe}$ and $\mathrm{Mn}$ except $\mathrm{Zn}$ which was low in

Table 6. Micronutrients percent samples under different categories in the study area.

\begin{tabular}{|c|c|c|c|c|c|c|c|c|c|c|c|c|}
\hline \multirow{2}{*}{$\begin{array}{l}\text { Valleys } \\
\mathrm{N}=96\end{array}$} & \multicolumn{3}{|c|}{$\mathbf{C u}$} & \multicolumn{3}{|c|}{$\mathbf{F e}$} & \multicolumn{3}{|c|}{$\mathbf{Z n}$} & \multicolumn{3}{|c|}{ Mn } \\
\hline & Low & Med & High & Low & Med & High & Low & Med & High & Low & Med & High \\
\hline \multirow{2}{*}{ Bagrote $(\mathrm{n}=24)$} & 00 & 00 & 24 & 00 & 00 & 24 & 13 & 8 & 3 & 00 & 00 & 24 \\
\hline & (0) & (0) & (100) & (0) & (0) & (100) & $(54.2)$ & (33.3) & (12.5) & (0) & (0) & (100) \\
\hline \multirow[t]{2}{*}{ Haramosh $(\mathrm{n}=28)$} & 00 & 00 & 28 & 00 & 1 & 27 & 18 & 4 & 6 & 00 & 00 & 28 \\
\hline & (0) & (0) & (100) & (0) & (3.58) & (96.42) & (64.29) & (14.29) & (21.42) & (0) & (0) & (100) \\
\hline \multirow[t]{2}{*}{ Hoper $(n=20)$} & 00 & 00 & 20 & 00 & 00 & 20 & 10 & 7 & 3 & 00 & 00 & 20 \\
\hline & (0) & (0) & (100) & (0) & (0) & (100) & $(50.0)$ & $(35.0)$ & (15.0) & (0) & (0) & (100) \\
\hline \multirow[t]{2}{*}{ Shigar $(n=24)$} & 00 & 00 & 24 & 00 & 00 & 24 & 13 & 8 & 3 & 00 & 00 & 24 \\
\hline & (0) & (0) & (100) & (0) & (0) & (100) & (54.17) & (33.33) & (12.50) & (0) & (0) & (100) \\
\hline \multirow[t]{2}{*}{ Mean } & 00 & 00 & 96 & 00 & 1 & 95 & 54 & 27 & 15 & 00 & 00 & 96 \\
\hline & (0) & (0) & (100) & (0) & $(0.90)$ & (99.10) & $(56.26)$ & $(28.12)$ & $(15.62)$ & (0) & (0) & (100) \\
\hline
\end{tabular}

Values outside \& in parenthesis denote number \& percent samples respectively

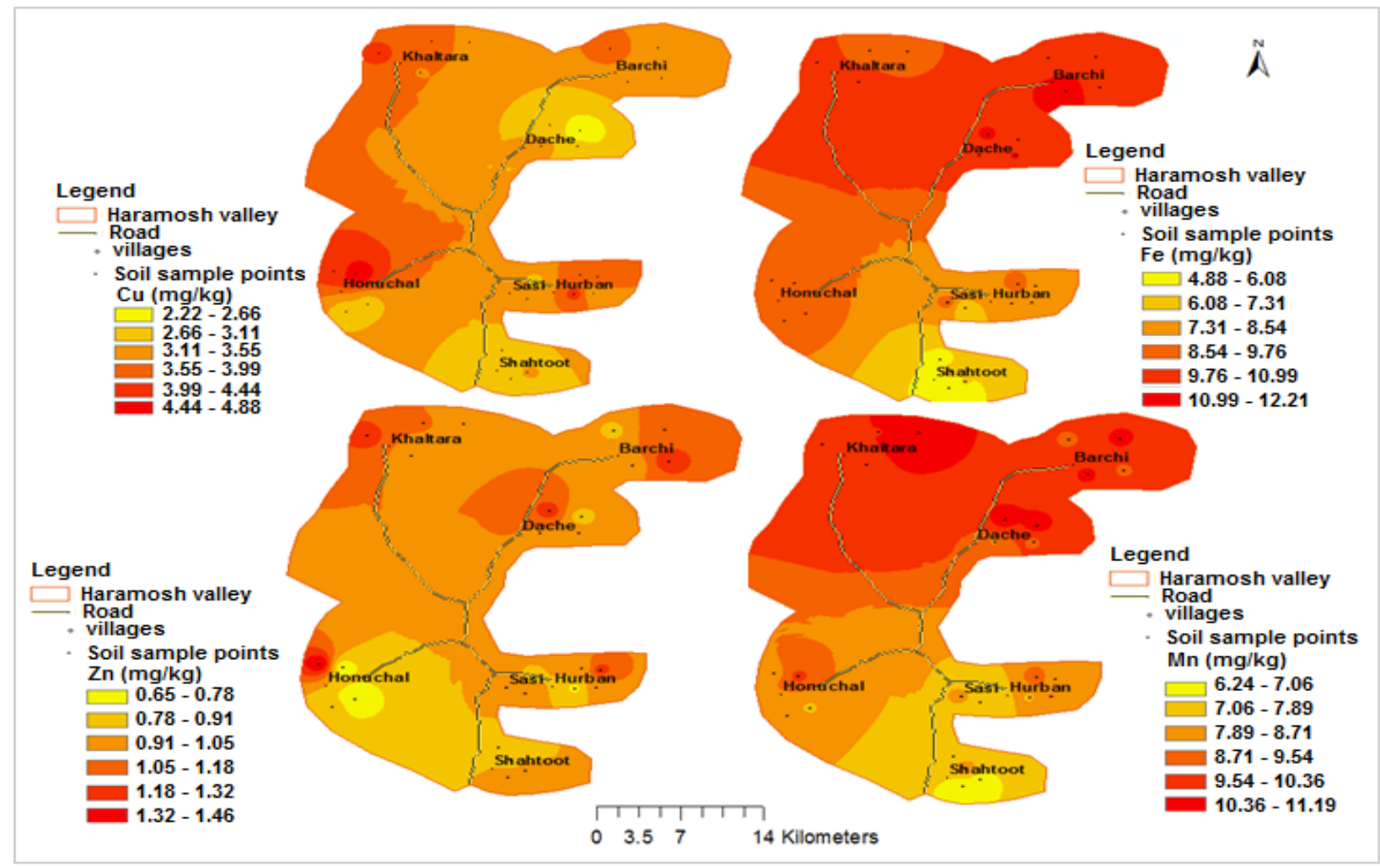

Figure 3. Mapping of micronutrient in villages of Haramosh valley. 
$54.1 \%$, medium $33.3 \%$ and high $12.5 \%$ in tested soil samples (Table 7). Macronutrients map showed that $58.5 \%, 83.3 \%$, $62.5 \%$ and $79.1 \%$ tested soil fall in the range of $3.42-3.91 \mathrm{mg}$ $\mathrm{kg}^{-1}$ of $\mathrm{Cu}, 12.0-13.55 \mathrm{mg} \mathrm{kg}^{-1} \mathrm{Fe}, 0.92-1.22 \mathrm{mg} \mathrm{kg}^{-1} \mathrm{Zn}$ and 10.12-11.09 $\mathrm{mg} \mathrm{kg}^{-1} \mathrm{Mn}$ (Fig. 5).

Soil mycoflora: In this part of the study, soil mycoflora was

Table 7. Mycoflora diversity and \% of occurrence in soil of Bagrote valley.

\begin{tabular}{|c|c|c|c|c|c|c|}
\hline Valley & Dilution & NCSD & NC/GS & Species & NC & \% occurrence \\
\hline \multirow[t]{13}{*}{ Bagrote } & $10^{-3}$ & 14 & & Rhizopus stolonifer & 2 & 8.33 \\
\hline & $10^{-4}$ & 7 & $24 \times 10^{-6}$ & Aspergillus flavus & 4 & 16.67 \\
\hline & $10^{-6}$ & 3 & & Alternaria alternata & 2 & 8.33 \\
\hline & Total & 24 & & Curvularia lunata & 1 & 4.17 \\
\hline & & & & Mucor species & 3 & 12.50 \\
\hline & & & & Rhizoctonia solani & 1 & 4.17 \\
\hline & & & & Fusarium solani & 2 & 8.33 \\
\hline & & & & Trichoderma harzanium & 2 & 8.33 \\
\hline & & & & Trichoderma viride & 1 & 4.17 \\
\hline & & & & Penicillium species & 2 & 8.33 \\
\hline & & & & Aspergillus niger & 2 & 8.33 \\
\hline & & & & Helminthosporium species & 1 & 4.17 \\
\hline & & & & Fusarium oxysporum, & 1 & 4.17 \\
\hline
\end{tabular}

NCSD: No of colonies in serial dilution; NC/GS: No of colonies per gram of soil; NC: No of colonies
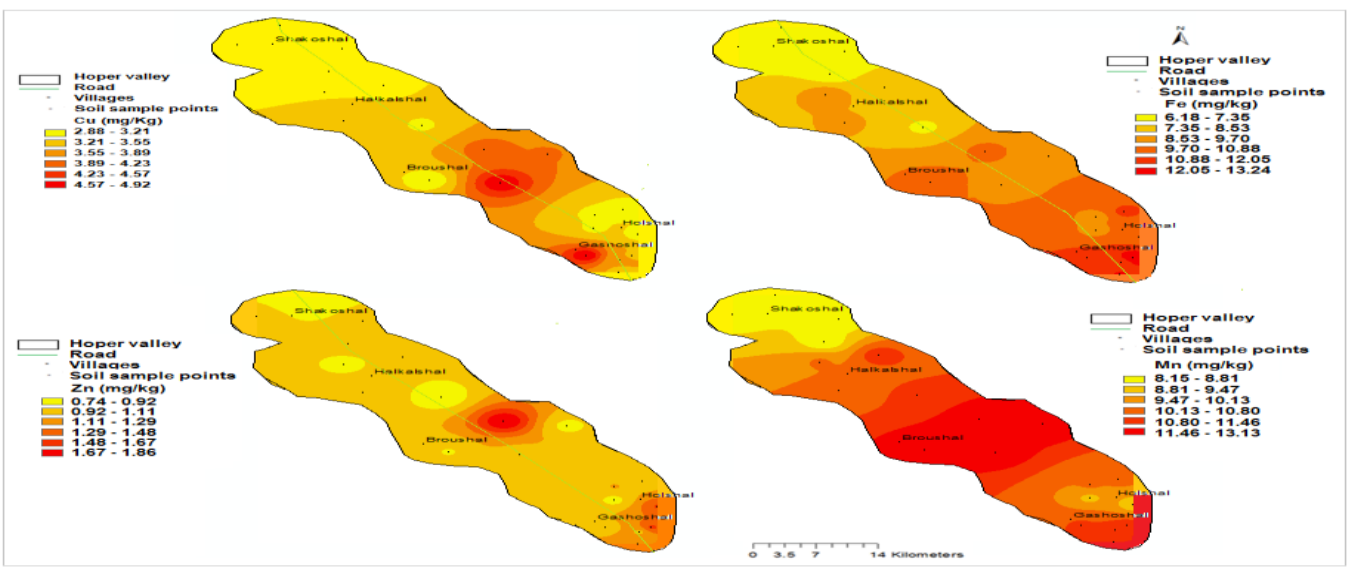

Figure 4. Mapping of micronutrient in villages of Hoper valley.

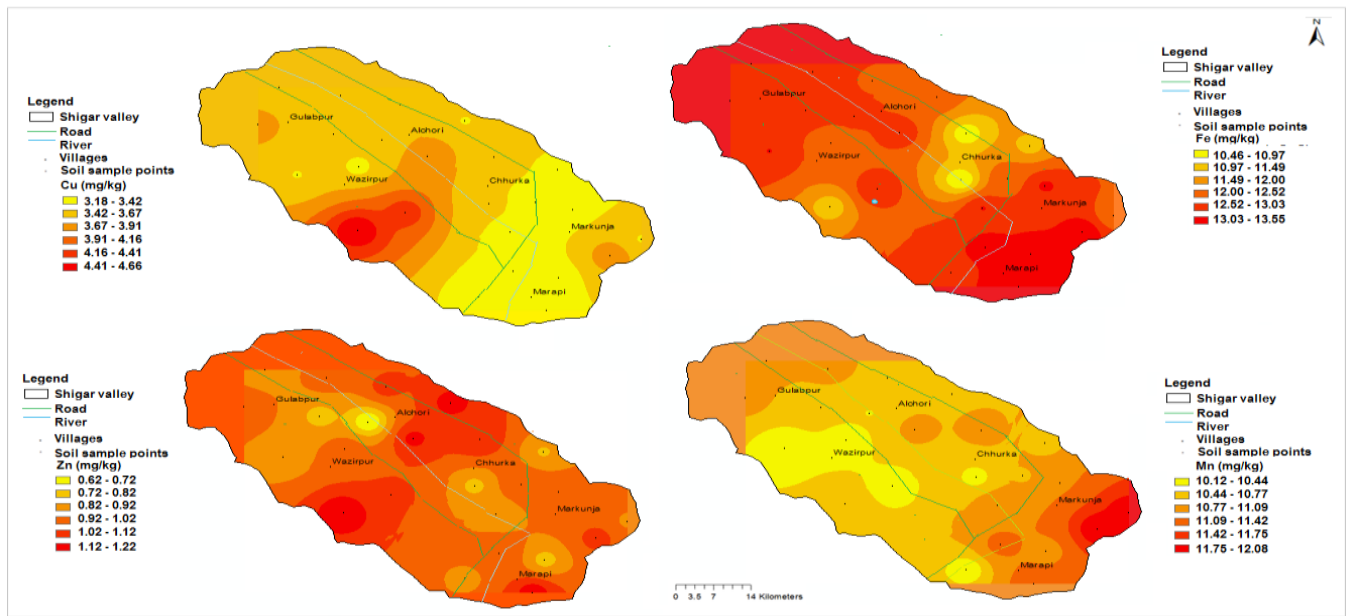

Figure 5. Mapping of micronutrient in villages of Shigar valley. 
enumerated through serial dilution technique from four composite samples (one from each valley). Results showed that a total of thirteen mycoflora were identified in the tested samples. Highest population of mycoflora was found in Shigar followed by Bagrote valley. The valley wise population of mycoflora in per gram of soil was recorded as $24 \times 10^{-6}$ in Bagrote, $18 \times 10^{-6}$ in Haramosh, $15 \times 10^{-6}$ in Hoper and $26 \times 10^{-6}$ in Shigar valley. Thirteen species were isolated in Bagrote valley with the highest number of Aspergillus flavus and Mucor species (Table 7). Similarly, ten mycoflora were isolated in soil samples of Haramosh valley with highest number of Rhizopus stolonifer and Penicillium species (Table 8). Nine mycoflora species were found in Hoper and thirteen in Shigar valley. Mucor species was found with highest percentage of occurrence in Hoper valley, whereas, Mucor and Penicillium were dominant followed by Alternaria alternata species in Shigar valley (Table 9, 10).

Table 8. Mycoflora diversity and \% of occurrence in soil of Haramosh valley.

\begin{tabular}{|c|c|c|c|c|c|c|}
\hline Valley & Dilution & NCSD & NC/GS & Species & $\mathbf{N C}$ & \% occurrence \\
\hline \multirow[t]{10}{*}{ Haramosh } & $10^{-3}$ & 8 & & Rhizopus stolonifer & 3 & 16.67 \\
\hline & $10^{-4}$ & 4 & $18 \times 10^{-6}$ & Aspergillus flavus & 2 & 11.11 \\
\hline & $10^{-6}$ & 2 & & Alternaria alternata & 1 & 5.55 \\
\hline & Total & 18 & & Curvularia lunata & 1 & 5.55 \\
\hline & & & & Mucor species & 2 & 11.11 \\
\hline & & & & Rhizoctonia solani & 1 & 5.55 \\
\hline & & & & Fusarium solani & 2 & 11.11 \\
\hline & & & & Trichoderma harzanium & 1 & 5.55 \\
\hline & & & & Penicillium species & 3 & 16.67 \\
\hline & & & & Aspergillus niger & 2 & 11.11 \\
\hline
\end{tabular}

NCSD: No of colonies in serial dilution; NC/GS: No of colonies per gram of soil; NC: No of colonies

Table 9. Mycoflora diversity and \% of occurrence in soil of Hoper valley.

\begin{tabular}{|c|c|c|c|c|c|c|}
\hline Valley & Dilution & NCSD & NC/GS & Species & $\mathbf{N C}$ & \% occurrence \\
\hline \multirow[t]{9}{*}{ Hoper } & $10^{-3}$ & 10 & & Rhizopus stolonifer & 2 & 13.33 \\
\hline & $10^{-4}$ & 3 & $15 \times 10^{-6}$ & Aspergillus flavus & 1 & 6.67 \\
\hline & $10^{-6}$ & 2 & & Alternaria alternata & 1 & 6.67 \\
\hline & Total & 15 & & Curvularia lunata & 2 & 13.33 \\
\hline & & & & Mucor species & 3 & 20.0 \\
\hline & & & & Trichoderma harzanium & 1 & 6.67 \\
\hline & & & & Penicillium species & 2 & 13.33 \\
\hline & & & & Aspergillus niger & 2 & 13.33 \\
\hline & & & & Helminthosporium species & 1 & 6.67 \\
\hline
\end{tabular}

NCSD: No of colonies in serial dilution; NC/GS: No of colonies per gram of soil; NC: No of colonies

Table 10. Mycoflora diversity and \% of occurrence in soil of Shigar valley.

\begin{tabular}{|c|c|c|c|c|c|c|}
\hline Valley & Dilution & NCSD & NC/GS & Species & NC & \% occurrence \\
\hline \multirow[t]{13}{*}{ Shigar } & $10^{-3}$ & 15 & & Rhizopus stolonifer & 1 & 3.84 \\
\hline & $10^{-4}$ & 7 & $26 \times 10^{-6}$ & Aspergillus flavus & 2 & 7.69 \\
\hline & $10^{-6}$ & 4 & & Alternaria alternata & 3 & 11.53 \\
\hline & Total & 26 & & Curvularia lunata & 1 & 3.84 \\
\hline & & & & Mucor species & 4 & 15.38 \\
\hline & & & & Rhizoctonia solani & 1 & 3.84 \\
\hline & & & & Fusarium solani & 2 & 7.69 \\
\hline & & & & Trichoderma harzanium & 1 & 3.84 \\
\hline & & & & Trichoderma viride & 2 & 7.69 \\
\hline & & & & Penicillium species & 4 & 15.38 \\
\hline & & & & Aspergillus niger & 1 & 3.84 \\
\hline & & & & Helminthosporium species & 2 & 7.69 \\
\hline & & & & Fusarium oxysporum, & 2 & 7.69 \\
\hline
\end{tabular}

NCSD: No of colonies in serial dilution; NC/GS: No of colonies per gram of soil; NC: No of colonies 


\section{DISCUSSION}

Soil $p H$, organic matter and Saturation percentage: Soil plays a foremost role in determining the sustainable productivity of agricultural crop. The sustainable agriculture development is a mainly depends upon the ability of soil to supply essential nutrients to the growing crop (Bell and Dell, 2008). The result of current study showed that $\mathrm{pH}$ of the study area was slightly alkaline, loamy or silty loam with low to medium organic matter contents. Similar results were obtained by (Baber et al., 2004; Whiteman, 1985. Soil pH is important parameter that influence physiochemical, biological and soil nutrient availability. Organic matter has a dynamic role in agricultural soil. It supplies plant nutrient to improve the soil structure, water infiltration and retention, feeds soil microflora and fauna (Johnston, 2007). The low or medium organic matter in the study area might be due to inadequate return of plant residues to the soil and environmental conditions which are conducive to rapid mineralization. Soil texture is basic to many other soil properties and helps as an indicator of water holding capacity, cation exchange capacity, aeration and organic matter content. Soil texture also controls the retention and losses of soil nutrients. In the current study saturation percentage raged from 35-50. According to Muhammad et al. (2015) stated that soil saturation percentage ranged from 26-46 are suitable for cultivation of all common crops.

Micronutrients: The results pertaining to micronutrients of study area indicated that $\mathrm{Cu}, \mathrm{Fe}$ and $\mathrm{Mn}\left(\mathrm{mg} \mathrm{kg}^{-1}\right)$ were high except $\mathrm{Zn}$ which showed irregular trends in the tested samples. Despite the sufficient amount of micronutrient concentrations in the soil of CKNP region, there is spatial variability between and within the villages. Several researchers reported that spatial variability of soil is due to intrinsic and extrinsic factors. Intrinsic factors are; soil formation factors, such as soil parent materials, while extrinsic factors are; soil management practices like fertilization (Mzuku et al., 2005; Guo-Shun et al., 2008; Denis et al., 2015). Variability is one of the intrinsic properties of soil quality and within the same ecosystem; soil characteristics may show significant spatial variations (Robinson et al., 2006). Main sources of micronutrients are parent material, sewage sludge, town refuse, farmyard manure (FYM) and organic matter (Wajahat et al., 2006). Whiteman 1985 reported that the $\mathrm{pH}$ of Northern Area now Gilgit-Baltistan is alkaline and found no widespread symptom of nutrient deficiency in these soils. Similar report was also contributed by Baber et al. 2004 in tehsil Gilgit which concluded that the tested soil samples were sufficient in $\mathrm{Cu}$, $\mathrm{Fe}$ and $\mathrm{Mn}$ except $\mathrm{Zn}$. This information's revealed that the study area is adequate in micronutrients which were in agreement with the current findings. It has been further reported that the agricultural systems where animal farming related practices are intensive, heavy metals can reach the soil due to application of liquid and solid manures. These practices are the main source of heavy metals and particularly $\mathrm{Cu}$ (Nicholson et al., 2003). The Zn deficiency of this region might be due to high $\mathrm{pH}$ and $\mathrm{CaCO}_{3}$ contents that precipitate as hydroxide and carbonates as reported by Vijayasekhar et al. (2000) on Indian soils. Management of soil nutrients is important for meeting the food requirements of everincreasing population of the world without adversely affecting the environment. Surveys and maps illustrating the geographic distribution of soil micronutrient availability provide guidance for proper management of nutrients in the soils. This information is further essential for a better understanding of the nature and extent of micronutrient deficiencies and toxicities in plants, livestock and humans (Jeffrey and Robert, 1999). GIS and geostatistics have been proven as an effective tool to assess the spatial variability of soil nutrients (Webster and Oliver, 2001). Spatial variability in soil nutrients of any area is necessary in order to gather information and prepare soil maps through spatial interpolation of point based measurements of soil characteristics (Santra et al., 2008). Micronutrient plays a significant role for growth and productivity of the crops and it contributes to ensure food security. In general, soil micronutrient status $(\mathrm{Cu}, \mathrm{Fe}$ and $\mathrm{Mn})$ are satisfactory except $\mathrm{Zn}$, however, in near future intensive cropping may possibly reduce their concentrations, therefore, integrated nutrient management practices are recommended. $\mathrm{Zn}$ status of the study area was medium to deficient that needs immediate attention for mitigation. GIS is used to produce micronutrient map of an area, which helps in formulating site specific fertilizer recommendations and to understand the status of soil micronutrients spatially.

Mycoflora diversity: Knowledge of mycoflora diversity and conservation in agricultural soil becomes very essential for the development of sustainable agriculture. Soil has a complex nature and dynamic environment in which the biological activities are mostly governed by microorganisms. Among the microorganisms; mycoflora are cosmopolitan in distribution and their population depends on the physicochemical properties of soil (Gomathi, 2011). The current investigation also revealed a variety of soil mycoflora which was in agreement of the above statement. Hawksworth (2002) reported that fungi is a main part of biodiversity, important for the survival of other organisms and plays a vital role in global ecological processes. It is omnipresent and occurs in all types of habitats and happens to be one of the most adaptable organisms. The results of the current study indicated that Aspergillus flavus and Penicillium species showed high percentage of occurrence in all valleys. Penicillium spp. are attributed to produce antibiotics and the Aspergillus spp. produce different kinds of toxins such as aflotoxins and achrotoxins etc. These toxins may prevent the growth of other fungal species (Chandrashekar et al., 2015; Shiny Niharika et al., 2013). It has been further reported that 
agricultural soils having diversity of fungal species are dominant by Aspergillus and Penicillium spp. (Rakesh and Raju, 2013). Aspergillus and Penicillium were dominating in all sites of the study area which was also confirmed by previous reports (Gnanasekaran et al., 2015; Gaddeyya et al., 2012; Shiny Niharika et al., 2013).

Conclusion: It is concluded that the soil of study area was slightly alkaline, loamy or silty loam with low to medium organic matter. GIS mapping showed that spatial variability of micronutrients was found. The results may be applied for determining the site specific nutrient management practices, fertilizer use efficiency, reducing cost of cultivation and preventing environmental pollution. Furthermore, mycoflora diversity was also observed in the study. Hence, the diversity of soil mycoflora of potato fields would provide information related to soil conservation and sustained ecological balance.

Acknowledgments: The author is grateful to SEED Project and KIU for granting scholarship for Ph.D. studies. The author would like to thank Dr. Sartaj Ali to carry out soil sampling in the study area and also his invaluable help in analysis and preparation of this manuscript.

\section{REFERENCES}

Ainsworth, G.C. and G.R. Bisby. 1995. Dictionary of the Fungi, $8^{\text {th }}$ Ed. Common Wealth Mycological Institute Kew., Surrey; p.445.

Arunachalam, K.A. R.S.T. Arunachalam and H.N. Pandey. 1997. Dynamics of microbial population during the aggradations phase of selectively logged sub-tropical humid forest in north-eastern India. Trop. Eco. 38:333341.

Ayoubia, S., S.M. Zamani and F. Khormali, 2007. Spatial variability of some soil properties for site specific farming in northern Iran. Int. J. Plant. Prod. 1:225-236.

Barnett, H.L and H. Bary. 1998. Illustrated Genera of Imperfect Fungi, $4^{\text {th }}$ Ed. Published by APS Press St., Paul, Minnesota.

Baber, K., R.A. Khattak and A. Hakeem. 2000. Physicochemical properties and fertility status of Gilgit soil. J. Agri. Res. 42:306-312.

Bell, R.W. and B. Dell. 2008. Micronutrients for Sustainable Food, Feed, Fibre and Bioenergy Production, $1^{\text {st }}$ Ed. IFA, Paris, France.

Chandrashekar, M.A., K. Soumya and N.S. Raju. 2014. Fungal diversity of rhizosphere soils in different agricultural fields of Nanjangud Taluk of Mysore District, Karnataka, India. Int. J. Curr. Microbiol. App. Sci. 3:559-566.

Christensen, M. 1989. A view of fungal ecology. Mycologia 81:1-19.
Corwin, D.L., S.M. Lesch, P.J. Shouse, R. Soppe and J.E. Ayers. 2003. Identifying soil properties that influence cotton yield using soil sampling directed by apparent soil electrical conductivity. Agron. J. 95:352-364.

Denis Magnus, K.A., D.A.M. Sheikh and Parameshgouda. 2015. Assessment of spatial variability of soil properties in hot semi-arid northern transition zone of India through remote sensing and geographic information system (GIS). AshEse. J. Agric. Sci. 1:043-053.

Hangsheng, L., W. Dan, B. Jay and W. Larry. 2005. Assessment of soil spatial variability at multiple scales. Ecol. Model. 182:271-290.

Eillis, M.B. 1993. Dematiaceous Hypomycetes. CAB International; Commonwealth Mycological Institute, Kew, Surrey, England.

Gaddeyya, G., P. Shiny, B.P. Niharika and R. Kumar. 2012. Isolation and identification of soil mycoflora in different crop fields at Salur Mandal. Adv. App. Sci. Res. 3:20202026.

Gilman, J.C.A. 2000. Manual of Soil Fungi, $2^{\text {nd }}$ Ed. Biotech Books, Delhi.

Gnanasekaran, P., S.S. Mohamed and A. Panneerselvam. 2015. Isolation and identification of soil mycoflora in banana field at Manachanallur, Tiruchirappalli Dt., Tamil Nadu, India. Int. J. Curr. Microbiol. App. Sci. 4:729-740.

Gomathi, S., V. Ambikapathy and A. Panneerselvam. 2011. Studies on soil mycoflora in chilli field of Thiruvarur District. Asian J. Res. Pharm. Sci. 1:117-122

Guo-Shun, L., W. Xin-Zhong, Z. Zheng-Yang and Z. ChunHua. 2008. Spatial variability of soil properties in a tobacco field of central China. Soil Sci. 173:659-667.

Hawksworth, D.L. 2000. Tropical Mycology, pp.1-11. Micromycetes CABI.

Iqbal, J., A. Thomasson, J.N. Jenkins, P.R. Owens and F.D. Whisler. 2005. Spatial variability analysis of soil physical properties of alluvial soils. Soil Sci. Soc. Am. J. 69:1338-1350.

Jansen, D.M., J.J. Stoorvoge and R.A. Shipper. 1995. Using sustainability indicators in agricultural land use analysis: an example from Costa Rica. Neth. J. Agric. Sci. 43:6182.

Jeffrey, G.W. and J.Z. Robert. 1999. Mapping soil micronutrients. Field Crop Res. 60:11-26.

Johnston, A.E. 2007. Soil organic matter, effects on soil and crop. Soil Use Manage. 2:97-105.

Kashem, M.A and B.R. Singh. 2001. Metal availability in contaminated soils: Effects of flooding and organic matter on changes in $\mathrm{Eh}, \mathrm{pH}$ and solubility of $\mathrm{Cd}, \mathrm{Ni}$ and Zn. Nutr. Cycl. Agroecosyst. 61:247-255.

Kartik, M.T., D. Nishith, S. Vijay, P. Ajay, M. Khalid and H.K. Manik. 2014. Spatial variability mapping of micronutrients to improve productivity using Geoinformatics Technology in Gujarat state, India. Int. J. Sci. Eng. Res. 5:1021-1027. 
Kiran, S., B. Jaishree and S.V.A. Sobha.1999. Effect of thiram on root growth, root nodules and nitrogen fixation in Glycine max (L). J. Soil Biol. and Eco. 19:11-14.

Mantovi, P., G. Bonazzi and N. Marmiroli. 2003. Accumulation of copper and zinc from liquid manure in agricultural soils and crop plants. Plant Soil 250:249257.

Milk, D.M., M.A. Khan and T.A. Choudhry. 1985. Analysis Manual for Soil, Water and Plants. Directorate of Soil Fertility and Soil Testing, Lahore, Pakistan.

Malik, D.M., B. Ahmed and M. Ahmed. 1984. Survey of soil fertility status and quality of ground waters. Punjab Digest 1981-84. Department of Agriculture, Punjab, Lahore, Pakistan.

McGill, W.B., K.R.Cannon, J.A. Robertson and F.D. Cook. 1980. Dynamics of soil microbial biomass and water stable organic carbon in Breton L after fifty years of cropping rotation. Can. J. Soil Sci. 66:1-19.

Muhammad, A., J. Qaiser, M. Ghulam and S. Mahmood. 2015. Soil Fertility Management for Sustainable Agriculture: A Case Study of District Bahawalnagar, Pakistan. J. Nat. Sci. Res. 19:57-63.

Mzuku, M., R. Khosla, R. Reich, D. Inman, F. Smith and L. MacDonald. 2005. Spatial variability of measured soil properties across site-specific management zones. Soil Sci. Soc. Am. J. 69:1572-1579.

Nagamani, A., I.K. Kunwar and C. Manoharachary. 2006. Hand book of soil fungi. I.K. International Private limited. New Delhi, India. ISBN 10: 818823771X.

Nelson, S.W. and I.E. Sommers. 1982. Total carbon, organic carbon and organic matter,.pp.539-80. In: A.L. Page (ed.), Methods of Soil Analysis. Chemical and Microbial Properties: Agron. No. 9. Part 2, $2^{\text {nd }}$ Ed. American Society of Agronomy, Madison, Wisconsin, USA.

Nicholson, F.A., S.R. Smith, B.J. Alloway, C. Carlton-Smith and B.J. Chambers. 2003. An inventory of heavy metal input to agricultural soil in England and Wales. Sci. Total. Environ. 311:205-219.

Oliver, M.A. 1997. Soil and human health: a review. Eur. J. Soil. Sci. 48:573-592.

Rattan, R.K. and P.D. Sharma. 2004. Main micronutrients available and their method of use. Proc. IFA International symposium on Micronutrients, pp.1-10.

Rakesh, M.S. and N.S. Raju. 2013. Frequency and percentage occurrence of soil mycoflora in different crop fields at HD Kote of Mysore district. Int. J. Envi. Sci. 3:15691576.

Robinson, T.P and G.M. Metternicht. 2006. Testing the performance of spatial interpolation techniques for mapping soil properties. Computer and Elect. Agric. 50:97-108.

Santra, V., K. Chropra and D. Chakraborty. 2008. Spatial variability of soil properties and its application in predicting surface map of hydraulic parameters in an agricultural farm. Curr. Sci. 95:937-945.

Sharma, P.K. 2007. Emerging technologies of remote sensing and GIS for development of spatial data infrastructure. J. Ind. Soc. Soil Sci. 52:384-406.

Shiny Niharika, P., G. Gaddeyya and P.K. Ratna Kumar. 2013. An investigation on soil mycoflora of different crop fields at Narasannapeta Mandal, Srikakulam District. Int. Res. J. Env. Sci. 2:38-44.

Sood, A., R.K. Setia, R.L. Bansal, P.K. Sharma and V.K. Nayyar. 2004. Spatial distribution of micronutrients in soil of Amritsar district using frontier technologies. Proc. Punjab Science Congress held at Guru, Nanak Dev., 7-9 Feb., University of Amritsar India.

Soltanpour, P.N and A.P. Schwab. 1977. A new soil test for simultaneous extraction of macro- and micro-nutrients in alkaline soils. Commun. Soil Sci. Plan. 8:195-207.

Soltanpour, PN. 1985. Use of AB-DTPA soil test to evaluate elemental availability and toxicity. Commun. Soil Sci. Plan. 16:323-338.

Sun, B., S.L. Zhou and Q.G. Zhao. 2003. Evaluation of spatial and temporal changes of soil quality based on geostatistical analysis in the hill region of subtropical China. Geoderma 115:85-99.

Vijayasekhar, R., B. Vittal Kuligod, P.K. Basavaraj, G.S. Dasog and S.B. Salimath. 2000. Studies on micronutrient status in important black soil series of UKP command. Karnataka. Andhra Agric. J. 47:141- 143.

Von, U.H.R. 1988. Nutrient cycling in soil management and smallholder development in the Pacific Islands. In: IBSRAM (Inter. Board for Soil Res. Manage.) Proc. Bangkok, p.21.

Wajahat, N., P. Sajida and S. Iftikhar. 2006. Status of micronutrients in soils of District Bhimber (Azad Jammu and Kashmir). J. Agric. Biol. Sci. 1:35-40.

Warcup, J.H. 1950. The soil plate method for isolation of fungi from soil. Nature 166:117-117.

Webster, R. and M.A. Oliver. 2001. Geostatistics for environmental scientists, $2^{\text {nd }}$ Ed. Wiley, New York. ISBN: 978-0-470-02858-2.

White, J.G. and R.J. Zasoski. 1999. Mapping soil micronutrients. Field Crop Res. 60:11-26.

Whiteman,P.T.S.1985. Soils. In: Mountain Oasis-a technical report on Agriculture studies in Gilgit District Northern Areas; pp.28-40. 